\title{
Syzygium aromaticum L. (Myrtaceae): Traditional Uses, Bioactive Chemical Constituents, Pharmacological and Toxicological Activities
}

\author{
Gaber El-Saber Batiha ${ }^{1,2, *,+}$, Luay M. Alkazmi ${ }^{3}$, Lamiaa G. Wasef ${ }^{1}$, \\ Amany Magdy Beshbishy ${ }^{2, \dagger}{ }^{,}$Eman H. Nadwa ${ }^{4,5}$ and Eman K. Rashwan ${ }^{6,7}$ \\ 1 Department of Pharmacology and Therapeutics, Faculty of Veterinary Medicine, Damanhour University, \\ Damanhour 22511, AlBeheira, Egypt; lamiaawasef@vetmed.dmu.edu.eg \\ 2 National Research Center for Protozoan Diseases, Obihiro University of Agriculture and Veterinary \\ Medicine, Nishi 2-13, Inada-cho, Obihiro 080-8555, Hokkaido, Japan; amanimagdi2008@gmail.com \\ 3 Biology Department, Faculty of Applied Sciences, Umm Al-Qura University, Makkah 21955, Saudi Arabia; \\ lmalkazmi@uqu.edu.sa \\ 4 Department of Pharmacology and Therapeutics, College of Medicine, Jouf University, \\ Sakaka 72345, Saudi Arabia; emanhassannadwa@yahoo.co.uk \\ 5 Department of Medical Pharmacology, Faculty of Medicine, Cairo University, Giza 12613, Egypt \\ 6 Department of Physiology, College of Medicine, Al-Azhar University, Assuit 71524, Egypt; \\ dremanrashwan2020@gmail.com \\ 7 Department of Physiology, College of Medicine, Jouf University, Sakaka 42421, Saudi Arabia \\ * Correspondence: dr_gaber_batiha@vetmed.dmu.edu.eg or gaberbatiha@gmail.com; \\ Tel./Fax: +20-45-271-6024 \\ + These authors contributed equally.
}

Received: 23 January 2020; Accepted: 28 January 2020; Published: 30 January 2020

\begin{abstract}
Herbal medicinal products have been documented as a significant source for discovering new pharmaceutical molecules that have been used to treat serious diseases. Many plant species have been reported to have pharmacological activities attributable to their phytoconstituents such are glycosides, saponins, flavonoids, steroids, tannins, alkaloids, terpenes, etc. Syzygium aromaticum (clove) is a traditional spice that has been used for food preservation and possesses various pharmacological activities. S. aromaticum is rich in many phytochemicals as follows: sesquiterpenes, monoterpenes, hydrocarbon, and phenolic compounds. Eugenyl acetate, eugenol, and $\beta$-caryophyllene are the most significant phytochemicals in clove oil. Pharmacologically, S. aromaticum has been examined toward various pathogenic parasites and microorganisms, including pathogenic bacteria, Plasmodium, Babesia, Theileria parasites, Herpes simplex, and hepatitis $C$ viruses. Several reports documented the analgesic, antioxidant, anticancer, antiseptic, anti-depressant, antispasmodic, anti-inflammatory, antiviral, antifungal, and antibacterial activity of eugenol against several pathogenic bacteria including methicillin-resistant Staphylococcus epidermidis and S. aureus. Moreover, eugenol was found to protect against $\mathrm{CCl}_{4-}$ induced hepatotoxicity and showed a potential lethal efficacy against the multiplication of various parasites including Giardia lamblia, Fasciola gigantica, Haemonchus contortus, and Schistosoma mansoni. This review examines the phytochemical composition and biological activities of clove extracts along with clove essential oil and the main active compound, eugenol, and implicates new findings from gas chromatography-mass spectroscopy (GC-MS) analysis.
\end{abstract}

Keywords: Syzygium aromaticum; pharmacological activities; clove; essential oil; bioactive chemical constituents 


\section{Introduction}

The traditional medicinal system based on the use of herbal remedies still plays an important role in the health care system. In recent decades, medicinal plants have been gaining wider acceptance due to the perception that these plants being natural products have lesser side effects and improved efficacy than their synthetic counterparts [1,2]. Currently, about $80 \%$ of the world's inhabitants rely on traditional medicines as a major form of their primary health care [3]. Pharmacologically, various herbal plants possess bactericidal, virucidal, fungicidal activities; they are used in embalmment, in food preservation, and have anti-inflammatory, antimicrobial, spasmolytic, sedative, analgesic, and local anesthetic activities [4,5]. Many plant species have been reported to have pharmacological activities attributable to their phytoconstituents such are glycosides, saponins, flavonoids, steroids, tannins, alkaloids, terpenes and accordingly [4]. Up to date, herbal remedies have been documented as a vital source for discovering novel pharmaceutical molecules that have been used to treat serious diseases. These identified phytochemicals have been considered a remarkable leading compound in the search for effective and new drugs [5].

Syzygium (S.) aromaticum, also known as clove, is a dried flower bud belonging to the Myrtaceae family that is indigenous to the Maluku islands in Indonesia but has recently been farmed in different places worldwide [6,7]. The clove tree is composed of leaves and buds (the commercial part of the tree) and the flowering bud production begins four years after plantation. Afterward, they are collected either by hand or using a natural phytohormone in the pre-flowering stage [6]. Interestingly, they are commercially used for many medicinal purposes and in the perfume industry, and clove is considered one of the spices that can be potentially used as preservatives in many foods, especially in meat processing, to replace chemical preservatives due to their antioxidant and antimicrobial properties $[6,8]$. Several reports have documented the antibacterial, antiviral, anticarcinogenic, and antifungal activities of some aromatic herbs including cinnamon, oregano, clove, thyme, and mint. However, clove has gained much attention among other spices due to its potent antimicrobial and antioxidant activities [9]. The effective role of clove in the inhibition of different degenerative diseases is attributed to the presence of various chemical constituents in high concentrations with antioxidant activity $[10,11]$. Clove essential oil (CEO) is traditionally used in the treatment of burns and wounds, and as a pain reliever in dental care as well as treating tooth infections and toothache. In addition to that, its use has been documented in various industrial applications and is used extensively in perfumes, soaps and as a cleansing vehicle in histological work [12]. Cloves are used in Indian and Chinese traditional medicine as a warming and stimulating agent [7]. Traditionally, cloves have been used for centuries in the treatment of vomiting; flatulence; nausea; liver, bowel and stomach disorders; and as a stimulant for the nerves. In tropical Asia, cloves have been documented to relieve different microorganisms as scabies, cholera, malaria, and tuberculosis. As well, in America, clove has been traditionally used in inhibiting food-borne pathogens to treat viruses, worms, candida, and different bacterial and protozoan infections [13]. Moreover, eugenol has been widely used in dentistry because it can penetrate the dental pulp tissue and enter the bloodstream [14]. Sesquiterpenes, isolated from clove were reported to have anti-carcinogenic activity [15].

\section{Chemical Constituents}

Pharmacologically, clove has been documented as the main source of phenolic molecules like hidroxibenzoic acids, flavonoids, hidroxiphenyl propens, hidroxicinamic acids, and eugenol $\left(\mathrm{C}_{10} \mathrm{H}_{12} \mathrm{O}_{2}\right)$ - which is the major bioactive molecule-and gallic acid derivatives like hidrolizable tannins that are found in high amounts in the fresh plant (Table 1) $[6,9,16]$. Moreover, clove contains flavonoids namely quercetin and kaempferol and phenolic acids like ferulic, caffeic, ellagic, and salicylic acids [6]. Clove flower buds contain up to $18 \%$ of essential oil which consists of eugenol, eugenol acetate and $\beta$-cariofileno [17]. Clove oil is colorless or pale yellow with a distinct clove flavor and taste. The differences in CEO content and composition depend mainly on several factors like pre-treatments, variety, agro-ecological conditions, and extraction processes [18]. Notably, Gülçin [19] reported 
the in vitro antioxidant effectiveness of eugenol and discussed the relationship between structure and activity. They showed that eugenol allows the donation of the hydrogen atom and subsequently fixes the phenoxil radical, which results in the formation of steady molecules that do not establish or increase oxidation. Additionally, the eugenol compound has a pleasant carbon chain link with the aromatic ring which can be involved in phenoxil radical stabilization by resonance. Gas chromatography-mass spectroscopy (GC-MS) analysis demonstrated the existence of 36 components in the CEO that was isolated by hydro-distillation including eugenol, $\beta$-caryophyllene, eugenylacetate, ethyl hexanoate, 2-heptanone, $\alpha$-humulene, calacorene, humulenol, and calamen-ene [20-23]. 
Table 1. International Union of Pure and Applied Chemistry (IUPAC) name and chemical formula of bioactive molecules isolated from S. aromaticum.

\begin{tabular}{|c|c|c|c|c|c|}
\hline Compd. & IUPAC Name & Chemical Formula & Compd. & IUPAC Name & Chemical Formula \\
\hline Eugenol & 2-Methoxy-4-(prop-2-en-1-yl)phenol & $\mathrm{C}_{10} \mathrm{H}_{12} \mathrm{O}_{2}$ & Gallic acid & 3,4,5-Trihydroxybenzoic acid & $\mathrm{C}_{7} \mathrm{H}_{6} \mathrm{O}_{5}$ \\
\hline$\beta$-Caryophyllene & $\begin{array}{l}\text { (1R,4E,9S)-4,11,11-Trimethyl-8- } \\
\text { methylidenebicyclo[7.2.0]undec-4-ene }\end{array}$ & $\mathrm{C}_{15} \mathrm{H}_{24}$ & Biflorin & $\begin{array}{l}\text { 5,7-dihydroxy-2-methyl-6-[(2S,3R,4R, } \\
\text { 5S,6R)-3,4,5-trihydroxy-6- } \\
\text { (hydroxymethyl)oxan-2-yl]chromen-4-one }\end{array}$ & $\mathrm{C}_{16} \mathrm{H}_{18} \mathrm{O}_{9}$ \\
\hline Vanillin & 4-Hydroxy-3-methoxybenzaldehyde & $\mathrm{C}_{8} \mathrm{H}_{8} \mathrm{O}_{3}$ & Myricetin & $\begin{array}{l}\text { 3,5,7-Trihydroxy-2-(3,4,5-trihydroxyphenyl)- } \\
\text { 4-chromenone }\end{array}$ & $\mathrm{C}_{15} \mathrm{H}_{10} \mathrm{O}_{8}$ \\
\hline $\begin{array}{l}\text { Crategolic acid } \\
\text { (Maslinic acid) }\end{array}$ & $\begin{array}{c}\text { (4aS,6aR,6aS,6bR,8aR,10R,11R,12a } R, \\
\text { 14bS)-10,11-dihydroxy-2,2,6a,6b,9,9, } \\
\text { 12a-heptamethyl-1,3,4,5,6,6a,7,8,8a,10, } \\
\text { 11,12,13,14b-tetradecahydropicene-4a- } \\
\text { carboxylic acid }\end{array}$ & $\mathrm{C}_{30} \mathrm{H}_{48} \mathrm{O}_{4}$ & Campesterol & $\begin{array}{c}(3 S, 8 S, 9 S, 10 R, 13 R, 14 S, 17 R)-17-[(2 R, 5 R)- \\
5,6 \text {-dimethylheptan-2-yl]-10,13-dimethyl- } \\
\text { 2,3,4,7,8,9,11,12,14,15,16,17-dodecahydro- } \\
\text { 1H-cyclopenta[a]phenanthren-3-ol }\end{array}$ & $\mathrm{C}_{28} \mathrm{H}_{48} \mathrm{O}$ \\
\hline Kaempferol & $\begin{array}{l}\text { 3,5,7-Trihydroxy-2-(4-hydroxyphenyl)- } \\
\text { 4H-chromen-4-one }\end{array}$ & $\mathrm{C}_{15} \mathrm{H}_{10} \mathrm{O}_{6}$ & Stigmasterol & $\begin{array}{c}\text { 3S,8S,9S,10R,13R,14S,17R)-17-[(E,2R,5S)-5- } \\
\text { ethyl-6-methylhept-3-en-2-yl]-10,13- } \\
\text { dimethyl-2,3,4,7,8,9,11,12,14,15,16,17- } \\
\text { dodecahydro-1H-cyclopenta[a] } \\
\text { phenanthren-3-ol }\end{array}$ & $\mathrm{C}_{29} \mathrm{H}_{48} \mathrm{O}$ \\
\hline Rhamnetin & $\begin{array}{l}\text { 2-(3,4-dihydroxyphenyl)-3,5-dihydroxy- } \\
\text { 7-methoxychromen-4-one }\end{array}$ & $\mathrm{C}_{16} \mathrm{H}_{12} \mathrm{O}_{7}$ & Oleanolic acid & $\begin{array}{c}(4 \mathrm{a} S, 6 \mathrm{a} R, 6 \mathrm{a} S, 6 \mathrm{~b} R, 8 \mathrm{a} R, 10 S, 12 \mathrm{a} R, 14 \mathrm{~b} S)-10- \\
\text { hydroxy-2,2,6a,6b,9,9,12a-heptamethyl-1,3, } \\
4,5,6,6 \mathrm{a}, 7,8,8 \mathrm{a}, 10,11,12,13,14 \mathrm{~b}- \\
\text { tetradecahydropicene-4a-carboxylic acid }\end{array}$ & $\mathrm{C}_{30} \mathrm{H}_{48} \mathrm{O}_{3}$ \\
\hline Eugenitin & $\begin{array}{l}\text { 5-Hydroxy-7-methoxy-2,6- } \\
\text { dimethylchromen-4-one }\end{array}$ & $\mathrm{C}_{12} \mathrm{H}_{12} \mathrm{O}_{4}$ & Bicornin & $\begin{array}{c}\text { [(12R,14S,15R,16R,17R)-4,5,6,22,23,29,30- } \\
\text { heptahydroxy-9,19,26-trioxo-14,15- } \\
\text { bis[(3,4,5-trihydroxybenzoyl)oxy]-2,10,13, } \\
\text { 18,25-pentaoxahexacyclo[18.9.3.03,8.012, } \\
\text { 17.024,32.027,31]dotriaconta-1(29),3,5,7,20, } \\
\text { 22,24(32),27,30-nonaen-16-yl] } \\
\text { 3,4,5-trihydroxybenzoate }\end{array}$ & $\mathrm{C}_{48} \mathrm{H}_{32} \mathrm{O}_{30}$ \\
\hline Eugenin & $\begin{array}{l}\text { 5-Hydroxy-7-methoxy-2- } \\
\text { methylchromen-4-one }\end{array}$ & $\mathrm{C}_{11} \mathrm{H}_{10} \mathrm{O}_{4}$ & Quercetin & $\begin{array}{l}\text { 2-(3,4-dihydroxyphenyl)-3,5,7- } \\
\text { trihydroxychromen-4-one }\end{array}$ & $\mathrm{C}_{15} \mathrm{H}_{10} \mathrm{O}_{7}$ \\
\hline Ellagic acid & $\begin{array}{l}\text { 2,3,7,8-Tetrahydroxy-chromeno } \\
\text { [5,4,3-cde]chromene-5,10-dione }\end{array}$ & $\mathrm{C}_{14} \mathrm{H}_{6} \mathrm{O}_{8}$ & Carvacrol & 2-methyl-5-propan-2-ylphenol & $\mathrm{C}_{10} \mathrm{H}_{14} \mathrm{O}$ \\
\hline
\end{tabular}




\section{Crude Clove Extracts Efficacies}

Several S. aromaticum molecules namely kaempferol, biflorin, 5, 7-dihydroxy-2-methylchromone8-C- $\beta$-D-glucopyranoside, orsellinic acid glucoside, myricetin, rhamnocitrin, gallic acid, oleanolic acid, ellagic acid, and flavonoids triglycosides have been documented for their effectiveness in inhibiting oral pathogens [24]. As the ethanolic S. aromaticum extract showed high antioxidant efficacy in addition to its hepatoprotective activity on liver damage caused by paracetamol treatment [25]. The possible explanation of increased serum enzymes in paracetamol-induced liver damage may be attributed to inhibition of intracellular enzymes through membrane stabilization efficacy, which corresponds to the view that the serum transaminases levels have been restored by recovering hepatic Pseudomonas aeruginosa and Escherichia coli renchyma and the hepatocytes regeneration [26]. Essawi and Srour [27] tested the antimicrobial efficacy of six medicinal herbal extracts in vitro toward four bacterial species methicillin-resistant Staphylococcus aureus and Bacillus subtilis were the most inhibited microorganisms. Syzygium aromaticum extract was the most active against multidrug-resistant. Joshi et al. [28] found that S. aromaticum was the most effective against Salmonella typhi. Moreover, Jirovetz et al. [17] showed that the flower bud extract of $S$. aromaticum (clove) showed antibacterial efficacy toward Bacillus and Serratia marcescens bacterial isolates. In addition, Oulkheir et al. [29] found that the CEO produced an inhibition zone against $E$. coli of $16 \mathrm{~mm}$ and a higher inhibitory zone $(20 \mathrm{~mm})$ against Salmonella species, while no antibacterial effect on K. pneumoniae. Haroun and Al-Kayali [30] noticed good synergism between ethanolic extract from S. aromaticum with different antibiotics compared with water extract against $S$. aureus isolate. Interestingly, previous reports investigated the antifungal effectiveness of eugenol and clove oil against yeasts, filamentous, and human pathogenic fungi [31-34]. Moreover, Nejad et al. [35] reported the antibacterial efficacy of various natural bioactive molecules namely thymol, eugenol, carvacrol, and cinnamaldehyde against the $E$. coli, and they revealed that eugenol resulted in the lowest antibacterial efficacy, whilst carvacrol and thymol, cinnamaldehyde and eugenol combined treatment revealed synergistic efficacy [36].

\section{Biological Activities}

\subsection{Biological/Biochemical Properties of S. aromaticum}

Han and Parker [37] have revealed the antiviral, antimicrobial, antifungal, anticancer, antioxidant, and anti-inflammatory activities of the CEO and its main active constituent eugenol, and they revealed that CEO influenced the cancer biology and cell cycle control. The problems of pathogen resistance, as well as the toxic residues to most of the commercially available antimicrobial drugs severely weaken their effective curative and protective approaches [37-39]. Therefore, it is clear that the development of new and effective antimicrobial treatment options is vital for improving disease treatment and control. Clove is a well-known and significant herbal remedy because of its broad pharmacological efficacy [40]. Recent studies have examined the in vivo increase in the lipid peroxidation and blood sugar in diabetic rats and reestablished the levels of the antioxidant enzyme after nutrition supplement with cloves [41]. Additionally, Shukri et al. [42] revealed that the dietary cloves in vivo reduced the tissue damages in the livers, lens, and cardiac muscles in rats. Pharmacologically, clove oil is used in a wide range as an antiseptic in oral diseases and for the treatment of toothaches, allergy disorders, asthma, acne, scars, and rheumatoid arthritis, and it showed antispasmodic and acaricidal effects toward Dermatophagoides pteronyssinus and Dermatophagoides farina [43,44]. Moreover, the CEO has shown aphrodisiac, antipyretic, appetizer, hypnotic, anxiolytic, antiemetic, analgesic, decongestant, antimicrobial, antiepileptic, myorelaxant, anti-inflammatory, and expectorant properties as well as has a medicinal influence against trophic disorder [37,45]. Notably, tannins, ellagic acid, gallic acid, flavonoids and their glycosides isolated from alcoholic and aqueous clove buds extracts were reported to have antithrombotic, antiprotozoal, hypoglycemic, anti-inflammatory, gastroprotective, and aphrodisiac efficacy [46-50]. In traditional medicine, clove has been used in flatulence, indigestion 
complaints and diarrhea [51]. The biological activities of S. aromaticum and its related compounds are shown in Figure 1.

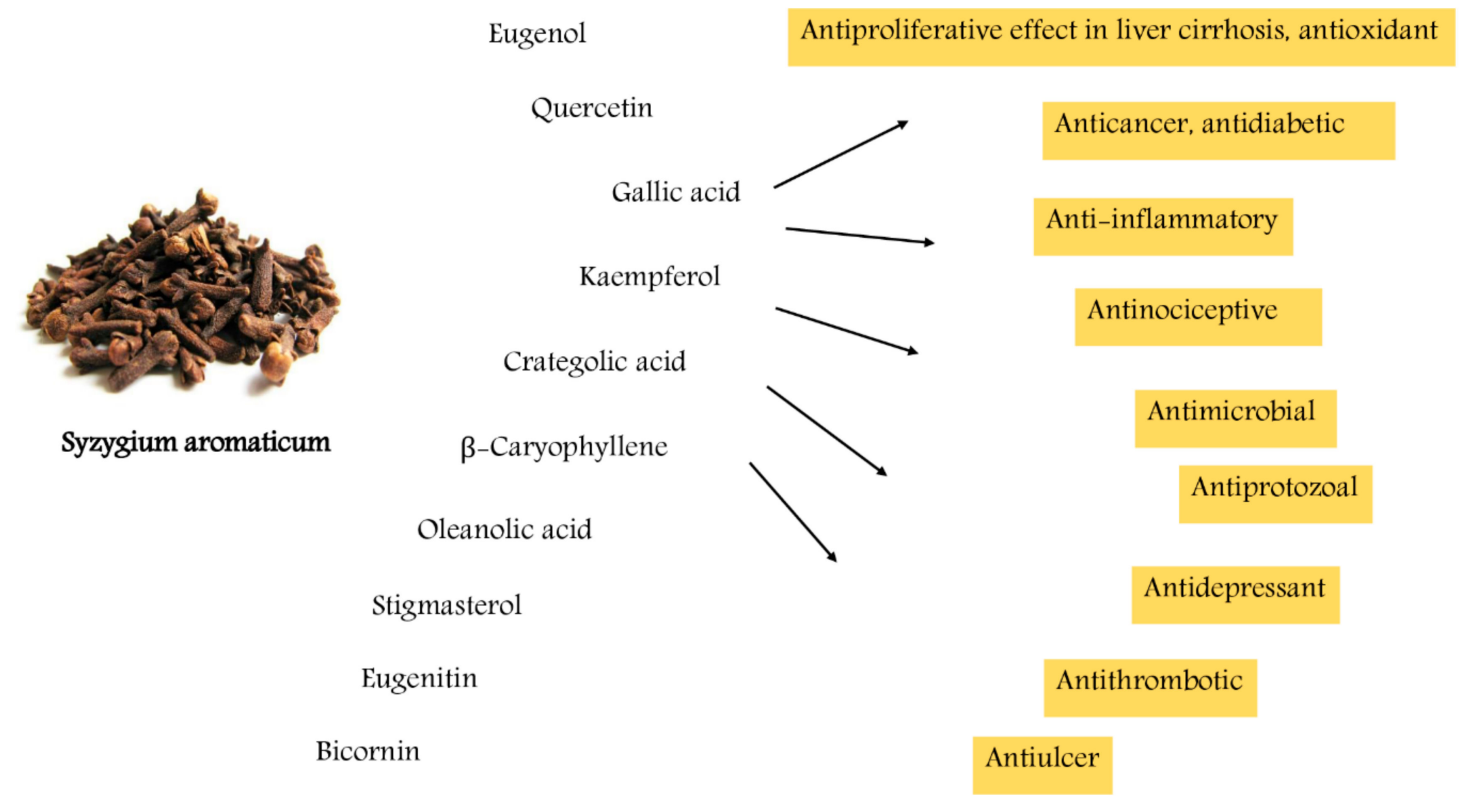

Figure 1. The biological activities of S. aromaticum and its related compounds.

Several reports demonstrated the antimicrobial efficacies of clove against different fungal and bacterial strains. For instance, Sofia et al. [52] examined the antimicrobial efficacy of several Indian spice herbs (e.g., ginger, garlic, mint, clove mustard, and cinnamon). Moreover, Dorman and Deans [53] evaluated the antibacterial efficacy of thyme, clove, geranium, nutmeg, oregano, and black pepper toward 25 strains of gram-negative and gram-positive bacteria. Thielmann et al. [54] documented that thyme, bay, oregano, and CEOs demonstrated different grades of inhibition against E. coli. As well, carvacrol and eugenol enclosed in a non-ionic surfactant were examined toward Listeria monocitogenes and E. coli, and the results revealed the effectiveness of eugenol to suppress these microorganisms multiplication [55]. Rana et al. [56] documented the antifungal efficacy of clove oil towards Trichophyton rubrum, Microsporum canis, T. mentagrophytes, Fusarium monoliforme, M. gypseum, F. oxysporum, Epidermophyton floccosum, Mucor sp., M. gypseum, T. rubrum, and Aspergillus sp. [57]. Fu et al. [58] as well as Palombo and Semple [59] reported the antibacterial effect of pure clove oil either alone or combined with rosemary oil towards P. aeruginosa, B. subtilis, S. epidermidis, S. aureus, Proteus vulgaris, E. coli, and methicillin-resistant S. epidermidis and S. aureus. Additionally, herbal remedies have been documented as a major source for discovering new pharmaceutical molecules to inhibit and control viral infections [60]. Eugeniin, the compound isolated from S. aromaticum extract has been documented for its antiviral efficacy towards various herpes virus strains and the hepatitis $C$ virus by its action on the synthesis of the viral DNA by inhibiting the viral DNA polymerase enzyme $[6,61]$. Another research revealed the antiviral efficacy of $S$. aromaticum aqueous extracts against herpes simplex virus type 1 (HSV-1) and influenza A virus when combined with acyclovir [62-65]. The possible antimicrobial action for clove oil is attributed to eugenol which consists of about $85 \%$ to $92 \%$ of total clove oil content [66].

Carvacrol and eugenol are the main components of clove responsible for its fungicidal characteristics against onychomycosis isolated fungi, T. mentagrophytes and Candida albicans $[31,67,68]$. Interestingly, Núñez et al. [69] reported the fungicidal activity of the mixture of a concentrated sugar solution with clove oleoresin by decreasing the inoculum size of fungi. Chami et al. [70] revealed remarkable morphological deterioration with cellular deformation in Saccharomyces cerevisiae cells caused by clove oil. Siripornvisal et al. [71] as well as Pinto et al. [72], examined the potent inhibitory 
antifungal effects of the CEO towards the mycelial multiplication of Botrytis cinerea and collection strains of dermatophyte, Aspergillus and Candida species. Recently, Batiha et al. [7] documented the antipiroplasmic effect of $S$. aromaticum methanolic extracts against piroplasm parasites multiplication. Moreover, the previous study described the in vitro antiplasmodial efficacy of methanolic S. aromaticum extracts against a chloroquine-resistant strain of Plasmodium falciparum, the closely related apicomplexan parasite to Babesia and Theileria [73].

\subsection{Efficacy in Diseases}

Several in vitro methods like 1, 1-diphenyl-2-picryl hydroxyl (DPPH) radical, b-carotene-linoleate, ferric thiocyanate, and hydroxyl radical revealed that caraway and clove antioxidant activity is consistent with the synthetic food preservative, butylated hydroxytoluene (BHT) [74]. Moreover, Gülçin et al. [75] measured the scavenging of the DPPH radical of clove oil in comparison to some artificial antioxidant agents, namely, alfa-tocopherol, BHT, Trolox, and butylated hydroxyanisole, and they demonstrated that the clove oil antioxidant activity declined as follows: clove oil $>$ BHT $>$ alfa-tocopherol $>$ butylated hydroxyanisole $>$ Trolox. Various in vitro methods including DPPH, oxygen radical absorbance capacity, ferric reducing antioxidant power, 2-deoxiguanosine, 2, 2' -azino-bis (3-ethylbenzothiazoline-6-sulphonic acid) (ABTS), and xanthine oxidase used to examine the antioxidant activity of aqueous $S$. aromaticum extract. They documented that the potent antioxidant efficacy of aqueous $S$. aromaticum extract may be due to the strong hydrogen donating ability, scavenging of hydrogen peroxide, free radicals and superoxide and metal chelating ability [76]. Antioxidant agents like clove extracts and the CEO play a significant role in treating memory deficits resulting from oxidative stress [77]. Halder et al. [78] revealed that CEO's pretreatment reduced the oxidative stress evaluated by glutathione as well as malondialdehyde levels in mice's brains. They concluded that the ability of clove oil to restore memory and learning deficiencies resulted from short- and long-term scopolamine treatment is attributed to its effectiveness in reducing oxidative stress.

Moreover, the analgesic effect of clove, as well as eugenol, have been documented against toothache, joint pain by activating chloride and calcium channels in ganglionar cells [79]. However, another study revealed that the analgesic activity of clove may be attributed to its capsaicin agonist activity [80]. Daniel et al. [81] reported the in vivo analgesic efficacy of eugenol using the abdominal wriggling method stimulated by acetic acid. Interestingly, the anti-carcinogenic and cytotoxic activities of the CEO have been reported against human tumor cell lines PC-3 and Hep G2 [15,82,83]. Chaieb et al. [23] documented that eugenol and dehydrodieugenol have been shown to stimulate human cancer cell death. Moreover, the antimutagenic efficacy of cinnamaldehyde has been investigated against human-derived hepatoma cells, as it inhibited the micronuclei incidence caused by different heterocyclic amines [84]. Natural products have confirmed to be the most efficient in terms of their ability to change the function of proteins related to cancer [85]. Kouidhi et al. [86] and Kumar et al. [87] established that CEO and eugenol possess anticancer activities against leukemia, lung, breast, and colorectal cancer cells. Clove exerted anti-inflammatory and immunomodulatory activities by suppressing the lipopolysaccharide (LPS) action as well as the nuclear factor- $\mathrm{kB}$ (NF- $\mathrm{kB}$ ) pathway. Han and Parker [37] reported that the anti-inflammatory activity of clove may be related to the active compound, eugenol.

Moreover, eugenol was found to protect against hepatotoxicity caused by $\mathrm{CCl}_{4}$ when administered with $\mathrm{CCl}_{4}$ therapy [88]. Interestingly, other phytochemical compounds isolated from S. aromaticum extracts including sanguinarine and benzo phenanthridine alkaloids have been documented for protection from liver damage [89]. Shyamala et al. [90] proved that clove intake tends to recover ALT, urea, AST, and lipid levels in kidneys, serum, and liver in comparison with normal values in hyperlipidemic rats. The antidiabetic efficacy of S. aromaticum extracts may be attributed to the existence of insulin-stimulating agents [91]. In vivo experiments revealed that the normal blood sugar has been enhanced in S. aromaticum extracts-treated mice [91,92]. It was found that the CEO contains many biologically active compounds with potent gastroprotective activities and this activity 
has been found due to its high flavonoid contents [93]. The in vitro and in vivo experiments have documented the antiobesity efficacy of $S$. aromaticum extracts by reducing the serum triglycerides and cholesterol levels [94]. Additionally, Jung et al. [95] documented that diet supplemented with S. aromaticum extracts decreased serum insulin, leptin, and hepatic lipid levels along with the body weight of high-fat diet mice, suggesting its prospect as a natural anti-obesity supplement and its ability to decrease the hepatic lipid accumulation.

Clove essential oils have been reported to increase blood circulation and raise body temperature [6]. Several reports documented that clove can reduce the risk of arterial sclerosis, cardiovascular disorders, and other disease associated with oxidative stress. Eugenol also exhibits reversible, dose-related vasodilator as well as negative inotropic activities in heart muscle and showed smooth muscle relaxant and hypotensive efficacy [96]. Clove has been documented to possess nervous stimulating as well as sexual behavior boosting effect in male mice [97], and this action may be attributed to their nervine enhancing activity. Moreover, it showed an increase in mating performance in mice compared to an increase in sexual motivation [97]. Cortés-Rojas et al. [6] reported the ability of clove oil to inhibit prevent premature ejaculation. The sexual behavior of clove in humans has been enhanced by stimulating the testosterone level. Clove oil has been documented as thromboxane synthesis and platelet aggregation inhibitors and showed an anticoagulant activity. Moreover, clove oil prevented the platelet aggregation caused by the platelet-activating factor, arachidonic acid or collagen, and the results revealed that clove oil is more efficient in inhibiting platelet-activating factor- and arachidonic acid-induced aggregation than collagen [98]. As well, eugenol was reported to prevent prostaglandin biosynthesis, thromboxane $\mathrm{B} 2$ formation, and platelet aggregation caused by arachidonic acid in vitro [99]. The myogenic antispasmodic effect of eugenol has been documented on the airway smooth muscle of rats. It was found to act by blocking $\mathrm{Ca}^{2+}$ channels managed by voltage and receptors, enhancing the release of $\mathrm{Ca}^{2+}$ from the sarcoplasmic reticulum and decreasing the sensitivity of the contractile proteins to $\mathrm{Ca}^{2+}$ [100]. In addition to that, it showed an antipyretic effect through a central action comparable with that of acetaminophen and allopathic antipyretic agents [101]. Eugenol and its analogs revealed anti-depressant efficacy in vivo by preventing monoamine oxidase [102].

\subsection{Efficacy of the Most Common Compound Eugenol}

Clove essential oil and eugenol derived from S. aromaticum have been documented to possess useful analgesic, anesthetic, and antiseptic effects and are therefore commonly used in dentistry [23]. In addition to that, they showed an anti-inflammatory efficacy against murine macrophages by suppressing the pro-inflammatory cytokines production $[103,104]$ and eugenol prohibited IL-8 production enhancement against human gingival fibroblasts (HGF) but not against skin keratinocytes (HaCat) or periodontal ligament fibroblasts (HPLF) [41]. Eugenol showed a strong antibacterial efficacy against different strains of Gram-positive and Gram-negative bacteria and revealed greater antimicrobial activity when combined with gentamicin, $\beta$-lactam and vancomycin antibiotics $[58,59]$. The antifungal efficacy of eugenol and clove oil has been investigated towards yeasts and filamentous fungi, including various human pathogenic fungi and food-borne fungal species [23,31-33]. Interestingly, several reports documented that eugenol isolated from S. aromaticum extracts have shown potent trypanocidal as well as leishmanicidal efficacy against Trypanosoma cruzi, Leishmania donovani, L. amazonensis, L. major and L. tropica $[105,106]$. Additionally, eugenol showed a potential lethal efficacy against the growth and multiplication of various parasites including Giardia lamblia, Fasciola gigantica, Haemonchus contortus, and Schistosoma mansoni [107,108]. Eugenol exhibited antiviral activity against HSV-1 and herpes simplex -2 (HSV-2) by preventing viral replication and reducing the viral infection [64]. Eugenol isolated from $S$. aromaticum extracts and their essential oils has shown its free radical scavenging, antioxidant, and antimicrobial properties [58,109].

The anti-inflammatory effects of eugenol were attributed to its effect to prevent neutrophil/macrophage chemotaxis and prostaglandin synthesis as well as cyclooxygenase II enzyme expressions [35]. Moreover, eugenol dimers exhibited a chemopreventive effect by inhibiting the cytokines expression 
in macrophages [110]. Eugenol has been suggested to possess recovery effects on arthritis and thus can be used in the treatment of arthritis [111]. Kim et al. [112] investigated the direct effect of eugenol in inhibiting NF- $\mathrm{KB}$ activation caused by tumor necrosis factor (TNF $\alpha$ ) and preventing cyclooxygenase activity (COX-2) in LPS stimulated macrophages with $\mathrm{IC}_{50}$ value equal to $2.7 \mu \mathrm{M}$ in the healthy cells. Additionally, eugenol protected macrophages cellular dysfunction caused by chemicals and stabilized the pro/anti-inflammatory mediators. Eugenol has been investigated for its anti-cancer activity against skin tumors, melanoma, gastric cancer, leukemia, and prostate cancer by oncogene regulation and the caspase-dependent pathway. For instance, eugenol and biphenyl (S)-6, 6'-dibromo-dehydrodieugenol provokes antiproliferative efficacy on neuroectodermal tumor cells by stimulating partial apoptosis [113]. The epoxide form of eugenol has been reported as a potent therapy for stimulating apoptosis in human breast cancer cells [114]. Moreover, eugenol prevented various oncogenes-related breast cancer namely, NF- $\kappa \mathrm{B}$ and cyclin D1 as well as blocked the breast cancer multiplication in a p53- independent manner and upregulated the flexible cyclin-dependent kinase inhibitor protein and this anti-proliferative activity was significantly noticed in xenograft human breast tumors. In vitro and in vivo studies demonstrated the anti-breast cancer activities of eugenol, suggesting that it could be used to enhance breast cancer treatment by targeting the E2F1/survivin pathway. Eugenol cytotoxic concentrations caused the ATP reduction and enhancing the glycolytic metabolites and polyamines in normal oral cells and oral squamous cell carcinoma, indicating the unprogrammed cell death induction [114]. Nam and Kim [115] revealed the ability of eugenol in preventing metastasis associated with oxidative stress by blocking the efficacy of matrix metalloproteinase-9 in PMA-induced HT1080 cells. Nowadays, combination chemotherapies are being reported as the most significant strategy for alleviating serious diseases, including cancer, to decrease the dose of the drugs, leading to a reduction in their toxic symptoms as well as drug resistance. Interestingly, Hemaiswarya and Doble [116] showed that eugenol and 5-fluorouracil combined treatment displayed a more cytotoxic effect toward cervical cancer cells (HeLa) indicating that eugenol is a good combinatorial agent by inducing cancer cells apoptosis.

Eugenol and clove oil have been documented to have a potent effect on fatty liver and dyslipidemia by a different mechanism of action [117], which involves oxidative stress by reducing the oxidative damage [118]. In vivo experiments showed that eugenol administration at $100 \mathrm{mg} / \mathrm{kg} 4$ days prior to and 6 days together with gentamicin suppressing the oxidative damage caused by gentamicin [119]. The antiulcer efficacy of eugenol may be associated with the presence of several factors that increase gastric mucus production and barrier resistance [120]. Moreover, Oliveira et al. [120] documented that eugenol pretreatment in rats decreased the gastric acid secretion, gastric ulcers, and pepsin activity caused by indomethacin treatment and increased the gastric mucin concentration.

\section{Pharmacokinetics Studies of Eugenol}

Eugenol metabolism has been examined in male and female healthy volunteers. Eugenol is known to be easily absorbed after oral administration and rapidly reaches plasma and blood with a half-life of 14 and $18 \mathrm{~h}$, respectively and its accumulative impact has been observed after its daily administration for treating neuropathic pain [101]. Afterward, eugenol is metabolized to glucuronic acid or sulfate conjugate in the liver. Methyleugenol was partially metabolized in the liver by the action of different CYP 450 enzymes to reactive 2', 3'-(allylic) epoxide or $1^{\prime}$ hydroxy-derivatives [121]. Eugenol metabolism has been indicated by the same bioactivation pathway and the genotoxic and carcinogenic form of eugenol seems likely to be insignificant when compared to methyleugenol and is excreted in the conjugated form in the urine during $24 \mathrm{~h}$ [122]. Secondary metabolic pathways include the oxidation of side-chain double bond to the epoxide and then hydrolyzation to diol and additional oxidation to isoeugenol accompanied by allylic oxidation and then reducing the side-chain double bond [122]. Less than $0.1 \%$ of the eugenol dose was secreted in the unmetabolized form in the urine, while $95 \%$ of its dose was restored in the urine, greater than $99 \%$ composed of phenolic conjugates and 50\% were found as eugenol-glucuronide and sulphate. The urine consists of eugenol conjugates and other metabolites (e.g., cis- and trans-isoeugenol, 4-hydroxy-3-methoxyphenyl-propane, 
3-(4- hydroxy-3-methoxyphenyl)-propionic acid, 3-(4-hydroxy-3-methoxyphenyl)-propane-1, 2-diol, and 3-(4-hydroxy3-methoxyphenyl)-propylene-1, 2-oxide) [121].

\section{Toxicity Doses}

Food and Drug Administration (FDA) has confirmed the safety of clove buds, clove oil, eugenol, and oleoresins as a food supplement; however, there has been considerable attention regarding its toxicity recently [123]. Prashar et al. [21] have examined the cytotoxic activities of CEO and eugenol in vitro against human fibroblasts and endothelial cells, and they documented they recognized them as safe. On the other hand, other reports revealed that eugenol has an allergic efficacy when used in dentistry [12,124]. Moreover, eugenol, as well as CEO, was reported to have a spermicidal effect in vitro in six male partners of infertile couples [125]. The World Health Organization (WHO) has proven that the acceptable daily amount of clove in humans is $2.5 \mathrm{mg} / \mathrm{kg}$ body weight [82]. The CEO toxic activity was assessed in Poecilia reticulata and Danio rerio aquarium fish species and it exhibited half-maximal lethal concentrations $\left(\mathrm{LD}_{50}\right)$ at $18.2 \pm 5.52$ and $21.7 \pm 0.8 \mathrm{mg} / \mathrm{mL}$ against Danio rerio and Poecilia reticulata after $96 \mathrm{~h}$, respectively [126]. Janes et al. [127] documented the acute side effects (e.g., disseminated intravascular coagulopathy, generalized seizures, and hepatotoxicity after CEO administration). Recently, Johannah et al. [50] demonstrated the remarkable detoxification and the cardiac health effects in humans by reducing lipid peroxidation and increasing the endogenous redox enzyme levels. Moreover, another in vivo study reported the allergic contact dermatitis of eugenol in guinea pigs [75].

\section{Conclusions}

This review examines the medicinal properties and all phytochemical molecules isolated from S. aromaticum. Carvacrol, eugenol, thymol, and cinnamaldehyde are the major constituents extracted from the CEO. Eugenol is the active substance of the CEO, and the FDA considered it a safe substance in general. The daily allowable human consumption of clove oil approved by the WHO Expert Committee on Food additives is $2.5 \mathrm{mg} / \mathrm{kg}$ body weight. Pharmacologically, clove and its main constituents possess antimicrobial, antioxidant, anti-inflammatory, analgesic, anticancer, and anesthetic effects. Moreover, they showed insecticidal, mosquito repellant, aphrodisiac, and antipyretic activities.

Author Contributions: G.E.-S.B., L.M.A., L.G.W., A.M.B., E.H.N., and E.K.R. wrote the paper. G.E.-S.B. and A.M.B. revised the paper. All authors have read and agreed to the published version of the manuscript.

Funding: This review received no external research funds.

Conflicts of Interest: The authors declare no conflict of interest.

\section{Abbreviations}

$\mathrm{CCl}_{4}$ : carbon tetrachloride; GC-MS; Gas chromatography-mass spectroscopy; S. aromaticum: Syzygium aromaticum; IUPAC: International Union of Pure and Applied Chemistry; CEO: clove essential oil; HSV-1: Herpes simplex virus type 1; HSV-2: herpes simplex -2; DPPH: 1, 1-diphenyl-2-picryl hydroxyl; BHT: butylated hydroxytoluene; ABTS: 2, 2' -azino-bis (3-ethylbenzothiazoline-6-sulphonic acid); LPS: lipopolysaccharide; HGF: human gingival

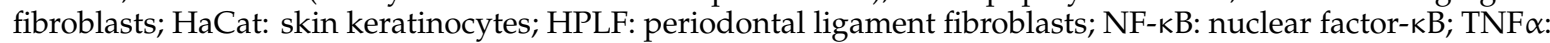
tumor necrosis factor; COX-2: cyclooxygenase activity; FDA: Food and Drug Administration; WHO: World Health Organization; $\mathrm{LD}_{50}$ : half-maximal lethal concentrations.

\section{References}

1. Abushouk, A.I.; Negida, A.; Ahmed, H.; Abdel-Daim, M.M. Neuroprotective mechanisms of plant extracts against MPTP induced neurotoxicity: Future applications in Parkinson's disease. Biomed. Pharmacother. 2017, 85, 635-645. [CrossRef]

2. Abushouk, A.I.; Ismail, A.; Salem, A.M.A.; Afifi, A.M.; Abdel-Daim, M.M. Cardioprotective mechanisms of phytochemicals against doxorubicin-induced cardiotoxicity. Biomed. Pharmacother. 2017, 90, 935-946. [CrossRef] [PubMed] 
3. Ekor, M. The growing use of herbal medicines: Issues relating to adverse reactions and challenges in monitoring safety. Front. Pharmacol. 2014, 4, 177. [CrossRef] [PubMed]

4. Batiha, G.E.S.; Beshbishy, A.A.; Tayebwa, D.S.; Shaheen, M.H.; Yokoyama, N.; Igarashi, I. Inhibitory effects of Uncaria tomentosa bark, Myrtus communis roots, Origanum vulgare leaves and Cuminum cyminum seeds extracts against the growth of Babesia and Theileria in vitro. Jap. J. Vet. Parasitol. 2018, 17, 1-13.

5. Beshbishy, A.M.; Batiha, G.E.S.; Adeyemi, O.S.; Yokoyama, N.; Igarashi, I. Inhibitory effects of methanolic Olea europaea and acetonic Acacia laeta on the growth of Babesia and Theileria. Asian Pac. J. Trop. Med. 2019, 12, $425-434$.

6. Cortés-Rojas, D.F.; de Souza, C.R.; Oliveira, W.P. Clove (Syzygium aromaticum): A precious spice. Asian Pac. J. Trop. Med. 2014, 4, 90-96. [CrossRef]

7. Batiha, G.E.S.; Beshbishy, A.A.; Tayebwa, D.S.; Shaheen, M.H.; Yokoyama, N.; Igarashi, I. Inhibitory effects of Syzygium aromaticum and Camellia sinensis methanolic extracts on the growth of Babesia and Theileria parasites. Ticks Tick. Borne Dis. 2019, 10, 949-958. [CrossRef]

8. Chomchalow, N. Spice production in Asia-An overview. In Proceedings of the Conference IBC's Asia Spice Markets 96 Conference, Singapore, 27-28 May 1996.

9. Shan, B.; Cai, Y.Z.; Sun, M.; Corke, H. Antioxidant capacity of 26 spice extracts and characterization of their phenolic constituents. J. Agric. Food Chem. 2005, 53, 7749-7759. [CrossRef]

10. Hu, F.B.; Willett, W.C. Optimal diets for prevention of coronary heart disease. JAMA 2002, 288, 2569-2578. [CrossRef]

11. Astuti, R.I.; Listyowati, S.; Wahyuni, W.T. Life span extension of model yeast Saccharomyces cerevisiae upon ethanol derived-clover bud extract treatment. IOP Conf. Ser. Earth Environ. Sci. 2019, 299, 012059. [CrossRef]

12. Sarrami, N.; Pemberton, M.; Thornhill, M.; Theaker, E.D. Adverse reactions associated with the use of eugenol in dentistry. Br. Dental J. 2002, 193, 253. [CrossRef]

13. Bhowmik, D.; Kumar, K.S.; Yadav, A.; Srivastava, S.; Paswan, S.; Dutta, A.S. Recent trends in Indian traditional herbs Syzygium aromaticum and its health benefits. J. Pharmaco. Phytochem. 2012, 1, 13-23.

14. Martínez-Herrera, A.; Pozos-Guillén, A.; Ruiz-Rodríguez, S.; Garrocho-Rangel, A.; Vértiz-Hernández, A.; Escobar-García, D.M. Effect of 4-Allyl-1-hydroxy-2-methoxybenzene (eugenol) on inflammatory and apoptosis processes in dental pulp fibroblasts. Mediators Inflamm. 2016, 2016, 9371403. [CrossRef] [PubMed]

15. Miyazawa, M.; Hisama, M. Suppression of chemical mutagen-induced SOS response by alkylphenols from clove (Syzygium aromaticum) in the Salmonella typhimurium TA1535/pSK1002 umu test. J. Agric. Food Chem. 2001, 49, 4019-4025. [CrossRef] [PubMed]

16. Neveu, V.; Perez-Jiménez, J.; Vos, F.; Crespy, V.; du Chaffaut, L.; Mennen, L.; Knox, C.; Eisner, R.; Cruz, J.; Wishart, D.; et al. Phenol-Explorer: An online comprehensive database on polyphenol contents in foods. Database 2010, 2010. [CrossRef] [PubMed]

17. Jirovetz, L.; Buchbauer, G.; Stoilova, I.; Stoyanova, A.; Krastanov, A.; Schmidt, E. Chemical Composition and Antioxidant properties of clove leaf essential oil. J. Agric. Food Chem. 2006, 54, 6303-6307. [CrossRef]

18. Hastuti, L.T.; Saepudin, E.; Cahyana, A.H.; Rahayu, D.U.C.; Murni, V.W.; Haib, J. The influence of sun drying process and prolonged storage on composition of essential oil from clove buds (Syzygium aromaticum). AIP Confer. Proceed. 2017, 1862, 030092.

19. Gülçin, İ. Antioxidant activity of eugenol: A structure-activity relationship study. J. Med. Food. 2011, 14, 975-985. [CrossRef]

20. Sulaiman, F.A.; Nafiu, M.O.; Yusuf, B.O.; Muritala, H.F.; Adeyemi, S.B.; Omar, S.A.; Dosumu, K.A.; Adeoti, Z.J.; Adegbesan, O.A.; Busari, B.O.; et al. The GC-MS fingerprints of Nicotiana tabacum L. extract and propensity for renal impairment and modulation of serum triglycerides in Wistar rats. J. Pharm. Pharmacogn. Res. 2020, $8,191-200$.

21. Prashar, A.; Locke, I.C.; Evans, C.S. Cytotoxicity of clove (Syzygium aromaticum) oil and its major components to human skin cells. Cell Prolif. 2006, 39, 241-248. [CrossRef]

22. Pawar, V.; Thaker, V. In vitro efficacy of 75 essential oils against Aspergillus niger. Mycoses 2006, 49, $316-323$. [CrossRef]

23. Chaieb, K.; Hajlaoui, H.; Zmantar, T.; Kahla-Nakbi, A.B.; Rouabhia, M.; Mahdouani, K.; Bakhrouf, A. The chemical composition and biological activity of clove essential oil, Eugenia caryophyllata (Syzygium aromaticum L. Myrtaceae): A short review. Phytother. Res. 2007, 21, 501-506. [CrossRef] [PubMed]

24. Koba, K.; Nenonene, A.Y.; Raynaud, C.; Chaumont, J.P.; Sanda, K. Antibacterial activities of the buds essential oil of Syzygium aromaticum (L.) Merr. \& Perry from Togo. J. Biol. Act. Prod. Nat. 2011, 1, 42-51. 
25. Nassar, M.; Gaara, A.; El-Ghorab, A.; Farrag, A.; Shen, H.; Huq, E.; Mabry, T.J. Chemical constituents of clove (Syzygium aromaticum, Fam. Myrtaceae) and their antioxidant activity. Latinoam. Quim. 2007, 35, 47.

26. Paarakh, P.M. Terminalia arjuna (Roxb.) Wt. and Arn.: A review. Int. J. Pharmacol. 2010, 6, 515-534. [CrossRef]

27. Essawi, T.; Srour, M. Screening of some Palestinian medicinal plants for antibacterial activity. J. Ethnopharmacol. 2000, 70, 343-349. [CrossRef]

28. Joshi, B.; Sah, G.P.; Basnet, B.B.; Bhatt, M.R.; Sharma, D.; Subedi, K.; Pandey, J.; Malla, R. Phytochemical extraction and antimicrobial properties of different medicinal plants: Ocimum sanctum (Tulsi), Eugenia caryophyllata (Clove), Achyranthes bidentata (Datiwan) and Azadirachta indica (Neem). J. Microbiol. Antimicrob. 2011, 3, 1-7.

29. Oulkheir, S.; Aghrouch, M.; EL Mourabit, F.; Dalha, F.; Graich, H.; Amouch, F.; Ouzaid, K.; Moukale, A.; Chadli, S. Antibacterial activity of essential oils extracts from cinnamon, thyme, clove and geranium against a gram-negative and gram-positive pathogenic bacteria. J. Dis. Med. Plants 2017, 3, 1-5.

30. Haroun, M.F.; Al-Kayali, R.S. Synergistic effect of Thymbra spicata L. extracts with antibiotics against multidrug-resistant Staphylococcus aureus and Klebsiella pneumoniae strains. Iran. J. Basic Med. Sci. 2016, 19, 1193-1200.

31. Velluti, A.; Sanchis, V.; Ramos, A.; Turon, C.; Marín, S. Impact of essential oils on growth rate, zearalenone and deoxynivalenol production by Fusarium graminearum under different temperature and water activity conditions in maize grain. J. Appl. Microbiol. 2004, 96, 716-724. [CrossRef]

32. Lopez, P.; Sanchez, C.; Batlle, R.; Nerín, C. Solid-and vapor-phase antimicrobial activities of six essential oils: Susceptibility of selected foodborne bacterial and fungal strains. J. Agric. Food Chem. 2005, 53, 6939-6946. [CrossRef] [PubMed]

33. Gayoso, C.; Lima, E.; Oliveira, V.; Pereira, F.O.; Souza, E.L.; Lima, I.O.; Navarro, D.F. Sensitivity of fungi isolated from onychomycosis to Eugenia cariophyllata essential oil and eugenol. Fitoterapia 2005, 76, 247-249. [CrossRef] [PubMed]

34. Chaieb, K.; Zmantar, T.; Ksouri, R.; Hajlaoui, H.; Mahdouani, K.; Abdelly, C.; Bakhrouf, A. Antioxidant properties of the essential oil of Eugenia caryophyllata and its antifungal activity against a large number of clinical Candida species. Mycoses 2007, 50, 403-406. [CrossRef] [PubMed]

35. Nejad, S.M.; Özgüneş, H.; Başaran, N. Pharmacological and toxicological properties of eugenol. Turk. J. Pharm. Sci. 2017, 14, 201-206. [CrossRef]

36. Pei, R.S.; Zhou, F.; Ji, B.P.; Xu, J. Evaluation of combined antibacterial effects of eugenol, cinnamaldehyde, thymol, and carvacrol against E. coli with an improved method. J. Food Sci. 2009, 74, M379-M383. [CrossRef]

37. Han, X.; Parker, T.L. Anti-inflammatory activity of clove (Eugenia caryophyllata) essential oil in human dermal fibroblasts. Pharm. Biol. 2017, 55, 1619-1622. [CrossRef]

38. Pappas, P.G.; Alexander, B.D.; Andes, D.R.; Hadley, S.; Kauffman, C.A.; Freifeld, A.; Anaissie, E.J.; Brumble, L.M.; Herwaldt, L.; Ito, J.; et al. Invasive fungal infections among organ transplant recipients: results of the Transplant-Associated Infection Surveillance Network (TRANSNET). Clin. Infect. Dis. 2010, 50, 1101-1111. [CrossRef]

39. Rapp, R.P. Changing strategies for the management of invasive fungal infections. Pharmacotherapy 2004, 24, 4S-28S. [CrossRef]

40. Bouchentouf, S.; Said, G.; Noureddine, M.; Hocine, A.; Angelika, B.A. A note study on antidiabetic effect of main molecules contained in clove using molecular modeling interactions with DPP-4 enzyme. Int. J. Comput. Theor. Chem. 2017, 5, 9-13.

41. Koh, T.; Murakami, Y.; Tanaka, S.; Machino, M.; Sakagami, H. Re-evaluation of anti-inflammatory potential of eugenol in IL-1beta-stimulated gingival fibroblast and pulp cells. In Vivo 2013, 27, 269-273.

42. Shukri, R.; Mohamed, S.; Mustapha, N.M. Cloves protect the heart, liver and lens of diabetic rats. Food Chem. 2010, 122, 1116-1121. [CrossRef]

43. Kim, E.H.; Kim, H.K.; Ahn, Y.J. Acaricidal activity of clove bud oil compounds against Dermatophagoides farinae and Dermatophagoides pteronyssinus (Acari: Pyroglyphidae). J. Agric. Food Chem. 2003, 51, 885-889. [CrossRef]

44. Wongsawan, K.; Chaisri, W.; Tangtrongsup, S.; Mektrirat, R. Bactericidal effect of clove oil against multidrug-resistant Streptococcus suis isolated from human patients and slaughtered pigs. Pathogens 2019, 9, E14. [CrossRef] [PubMed]

45. Elwakeel, H.; Moneim, H.; Farid, M.; Gohar, A.A. Clove oil cream: A new effective treatment for chronic anal fissure. Colorectal Dis. 2007, 9, 549-552. [CrossRef] [PubMed] 
46. Beshbishy, A.M.; Batiha, G.E.; Yokoyama, N.; Igarashi, I. Ellagic acid microspheres restrict the growth of Babesia and Theileria in vitro and Babesia microti in vivo. Parasit Vectors. 2019, 12, 269. [CrossRef] [PubMed]

47. Batiha, G.E.S.; Beshbishy, A.M.; Tayebwa, D.S.; Adeyemi, O.S.; Shaheen, H.; Yokoyama, N.; Igarashi, I. The effects of trans-chalcone and chalcone 4 hydrate on the growth of Babesia and Theileria. PLoS Negl. Trop. Dis. 2019, 13, e0007030. [CrossRef] [PubMed]

48. Ahmad, S.; Latif, A.; Qasmi, I.A. Effect of 50\% ethanolic extract of Syzygium aromaticum (L.) Merr. \& Perry. (Clove) on the sexual behaviour of normal male rats. BMC Complement. Altern. Med. 2004, 4, 17.

49. Issac, A.; Gopakumar, G.; Kuttan, R.; Maliakel, B.; Krishnakumar, I.M. Safety and anti-ulcerogenic activity of a novel polyphenol-rich extract of clove buds (Syzygium aromaticum L). Food Funct. 2015, 6, 842-852. [CrossRef]

50. Johannah, N.; Renny, R.; Gopakumar, G.; Balu, M.; Sureshkumar, D.; Krishnakumar, I.M. Beyond the flavour: A de-flavored polyphenol-rich extract of clove buds (Syzygium aromaticum $\mathrm{L}$ ) as a novel dietary antioxidant ingredient. Food Funct. 2015, 6, 3373-3382.

51. Hochenegg, B. Evaluation of the traditional and well-established use of Tormentillae rhizoma, Caryophylli flos and Caryophylli aetheroleum. Thesis Univ. Wien Germany Uniwien 2010. [CrossRef]

52. Sofia, P.K.; Prasad, R.; Vijay, V.K.; Srivastava, A.K. Evaluation of antibacterial activity of Indian spices against common foodborne pathogens. Int. J. Food Sci. Technol. 2007, 42, 910-915. [CrossRef]

53. Dorman, H.; Deans, S.G. Antimicrobial agents from plants: Antibacterial activity of plant volatile oils. J. Appl. Microbiol. 2000, 88, 308-316. [CrossRef]

54. Thielmann, J.; Muranyi, P.; Kazman, P. Screening essential oils for their antimicrobial activities against the foodborne pathogenic bacteria Escherichia coli and Staphylococcus aureus. Heliyon 2019, 5, e01860. [CrossRef]

55. Mytle, N.; Anderson, G.; Doyle, M.; Smith, M.A. Antimicrobial activity of clove (Syzgium aromaticum) oil in inhibiting Listeria monocytogenes on chicken frankfurters. Food Control 2006, 17, 102-107. [CrossRef]

56. Rana, I.S.; Rana, A.S.; Rajak, R.C. Evaluation of antifungal activity in essential oil of the Syzygium aromaticum (L.) by extraction, purification and analysis of its main component eugenol. Braz. J. Micr. 2011, 42, 1269-1277. [CrossRef] [PubMed]

57. Park, M.J.; Gwak, K.S.; Yang, I.; Choi, W.S.; Jo, H.J.; Chang, J.W.; Jeung, E.B.; Choi, I.G. Antifungal activities of the essential oils in Syzygium aromaticum (L.) Merr. Et Perry and Leptospermum petersonii Bailey and their constituents against various dermatophytes. J. Microbiol. 2007, 45, 460-465. [PubMed]

58. Fu, Y.; Zu, Y.; Chen, L.; Shi, X.; Wang, Z.; Sun, S.; Efferth, T. Antimicrobial activity of clove and rosemary essential oils alone and in combination. Phytother. Res. 2007, 21, 989-994. [CrossRef] [PubMed]

59. Palombo, E.A.; Semple, S.J. Antibacterial activity of Australian plant extracts against methicillin-resistant Staphylococcus aureus (MRSA) and vancomycin-resistant enterococci (VRE). J. Basic Microbiol. 2002, 42, 444-448. [CrossRef]

60. Astani, A.; Reichling, J.; Schnitzler, P. Screening for antiviral activities of isolated compounds from essential oils. Evid. Based Complement. Alternat. Med. 2011, 2011, 8. [CrossRef]

61. Hussein, G.; Miyashiro, H.; Nakamura, N.; Hattori, M.; Kakiuchi, N.; Shimotohno, K. Inhibitory effects of Sudanese medicinal plant extracts on hepatitis C virus (HCV) protease. Phytother. Res. 2000, 14, 510-516. [CrossRef]

62. Minami, M.; Kita, M.; Nakaya, T.; Yamamoto, T.; Kuriyama, H.; Imanishi, J. The inhibitory effect of essential oils on herpes simplex virus type-1 replication in vitro. Microbiol. Immunol. 2003, 47, 681-684. [CrossRef] [PubMed]

63. Nolkemper, S.; Reichling, J.; Stintzing, F.C.; Carle, R.; Schnitzler, P. Antiviral effect of aqueous extracts from species of the Lamiaceae family against Herpes simplex virus type 1 and type 2 in vitro. Planta Med. 2006, 72, 1378-1382. [CrossRef] [PubMed]

64. Reichling, J.; Schnitzler, P.; Suschke, U.; Saller, R. Essential oils of aromatic plants with antibacterial, antifungal, antiviral, and cytotoxic properties-an overview. Forsch. Komplementmed. 2009, 16, 79-90. [CrossRef] [PubMed]

65. Gilling, D.H.; Kitajima, M.; Torrey, J.R.; Bright, K.R. Mechanisms of antiviral action of plant antimicrobials against Murine norovirus. Appl. Environ. Microbiol. 2014, 80, 4898-4910. [CrossRef]

66. Aboubakr, H.A.; Nauertz, A.; Luong, N.T.; Agrawal, S.; El-Sohaimy, S.A.; Youssef, M.M.; Goyal, S.M. In vitro antiviral activity of clove and ginger aqueous extracts against Feline Calicivirus, a Surrogate for Human Norovirus. J. Food Prot. 2016, 79, 1001-1112. [CrossRef]

67. Manohar, V.; Ingram, C.; Gray, J.; Talpur, N.A.; Echard, B.W.; Bagchi, D.; Preuss, H.G. Antifungal activities of origanum oil against Candida albicans. Mol. Cell Biochem. 2001, 228, 111-117. [CrossRef]

68. Tampieri, M.P.; Galuppi, R.; Macchioni, F.; Carelle, M.S.; Falcioni, L.; Cioni, P.L.; Morelli, I. The inhibition of Candida albicans by selected essential oils and their major components. Mycopathologia 2005, 159, 339-345. [CrossRef] 
69. Núñez, L.; D’aquino, M.; Chirife, J. Antifungal properties of clove oil (Eugenia caryophylata) in sugar solution. Braz. J. Microb. 2001, 32, 123-126. [CrossRef]

70. Chami, F.; Chami, N.; Bennis, S.; Bouchikhi, T.; Remmal, A. Oregano and clove essential oils induce surface alteration of Saccharomyces cerevisiae. Phytother. Res. 2005, 19, 405-408. [CrossRef]

71. Siripornvisal, S.; Rungprom, W.; Sawatdikarn, S. Antifungal activity of essential oils derived from some medicinal plants against grey mould (Botrytis cinerea). As. J. Food Ag-Ind. 2009, 2, S229-S233.

72. Pinto, E.; Pina-Vaz, C.; Salgueiro, L.; Gonçalves, M.J.; Costa-de-Oliveira, S.; Cavaleiro, C.; Palmeira, A.; Rodrigues, A.; Martinez-de-Oliveira, J. Antifungal activity of the essential oil of Thymus pulegioides on Candida, Aspergillus and dermatophyte species. J. Med. Microbiol. 2006, 55, 1367-1373. [CrossRef] [PubMed]

73. Bagavan, A.; Rahuman, A.A.; Kaushik, N.K.; Sahal, D. In vitro antimalarial activity of medicinal plant extracts against Plasmodium falciparum. Parasitol. Res. 2011, 108, 15-22. [CrossRef] [PubMed]

74. Bamdad, F.; Kadivar, M.; Karamat, J. Evaluation of phenolic content and antioxidant activity of Iranian caraway in comparison with clove and BHT using model systems and vegetable oil. Int. J. Food Sci. Technol. 2006, 41, 20-27. [CrossRef]

75. Gülçin, İ.; Elmastaş, M.; Aboul-Enein, H.Y. Antioxidant activity of clove oil-A powerful antioxidant source. Arab. J. Chem. 2012, 5, 489-499. [CrossRef]

76. Gülçin, İ.; Şat, İ.G.; Beydemir, Ş.; Elmastaş, M.; Küfrevioğlu, Ö.İ. Comparison of antioxidant activity of clove (Eugenia caryophylata Thunb) buds and lavender (Lavandula stoechas L.). Food Chem. 2004, 87, 393-400. [CrossRef]

77. Mehta, K.D.; Garg, G.R.; Mehta, A.K.; Arora, T.; Sharma, A.K.; Khanna, N.; Tripathi, A.K.; Sharma, K.K. Reversal of propoxur-induced impairment of memory and oxidative stress by $4^{\prime}$-chlorodiazepam in rats. Naunyn. Schmiedebergs Arch. Pharmacol. 2010, 381, 1. [CrossRef]

78. Halder, S.; Mehta, A.K.; Kar, R.; Mustafa, M.; Mediratta, P.K.; Sharma, K.K. Clove oil reverses learning and memory deficits in scopolamine-treated mice. Planta Med. 2011, 77, 830-834. [CrossRef]

79. Shields, K.M.; McQueen, C.E.; Bryant, P.J. National survey of dietary supplement resources at drug information centers. J. Amer. Pharm. Assoc. 2004, 44, 36-40. [CrossRef]

80. Vriens, J.; Nilius, B.; Vennekens, R. Herbal compounds and toxins modulating TRP channels. Curr. Neuropharmacol. 2008, 6, 79-96.

81. Daniel, A.N.; Sartoretto, S.M.; Schmidt, G.; Caparroz-Assef, S.M.; Bersani-Amado, C.A.; Cuman, R.K.N. Anti-inflammatory and antinociceptive activities A of eugenol essential oil in experimental animal models. Revista Brasileira de Farmacognosia 2009, 19, 212-217. [CrossRef]

82. Ogunwande, I.; Olawore, N.; Ekundayo, O.; Walker, T.M.; Schmidt, J.M.; Setzer, W.N. Studies on the essential oils composition, antibacterial and cytotoxicity of Eugenia uniflora L. Int. J. Aromather. 2005, 15, 147-152. [CrossRef]

83. Yoo, C.B.; Han, K.T.; Cho, K.S.; Ha, J.; Park, H.J.; Nam, J.H.; Kil, U.H.; Lee, K.T. Eugenol isolated from the essential oil of Eugenia caryophyllata induces reactive oxygen species-mediated apoptosis in HL-60 human promyelocytic leukemia cells. Cancer Lett. 2005, 225, 41-52. [CrossRef] [PubMed]

84. Lin, L.T.; Wu, S.J.; Lin, C.C. The anticancer properties and apoptosis-inducing mechanisms of cinnamaldehyde and the herbal prescription Huang-Lian-Jie-Du-Tang (Huáng Lián Jiě Dú Tang) in human hepatoma cells. J. Tradit. Complement. Med. 2013, 3, 227-233. [CrossRef] [PubMed]

85. Russo, A.; Formisano, C.; Rigano, D.; Senatore, F.; Delfine, S.; Cardile, V.; Rosselli, S.; Bruno, M. Chemical composition and anticancer activity of essential oils of Mediterranean sage (Salvia officinalis L.) grown in different environmental conditions. Food Chem. Toxicol. 2013, 55, 42-47. [CrossRef] [PubMed]

86. Kouidhi, B.; Zmantar, T.; Bakhrouf, A. Anticariogenic and cytotoxic activity of clove essential oil (Eugenia caryophyllata) against a large number of oral pathogens. Ann. Microb. 2010, 60, 599-604. [CrossRef]

87. Kumar, P.; Febriyanti, R.; Sofyan, F.; Luftimas, D.E.; Abdulah, R. Anticancer potential of Syzygium aromaticum L. in MCF-7 human breast cancer cell lines. Pharmac. Res. 2014, 6, 350-354. [CrossRef]

88. El-Hadary, A.E.; Ramadan Hassanien, M.F. Hepatoprotective effect of cold-pressed Syzygium aromaticum oil against carbon tetrachloride $\left(\mathrm{CCl}_{4}\right)$-induced hepatotoxicity in rats. Pharmaceut. Biol. 2016, 54, 1364-1372. [CrossRef]

89. Ali, S.; Prasad, R.; Mahmood, A.; Routray, I.; Shinkafi, T.S.; Sahin, K.; Kucuk, O. Eugenol-rich fraction of Syzygium aromaticum (Clove) reverses biochemical and histopathological changes in liver cirrhosis and inhibits hepatic cell proliferation. J. Cancer Prevent. 2014, 19, 288-300. [CrossRef]

90. Shyamala, M.P.; Venukumar, M.R.; Latha, M.S. Antioxidant potential of the Syzygium aromaticum (gaertn) linn (cloves) in rats fed with high-fat diet. Indian J. Pharmacol. 2003, 35, 99-103. 
91. Kuroda, M.; Mimaki, Y.; Ohtomo, T.; Yamada, J.; Nishiyama, T.; Mae, T.; Kishida, H.; Kawada, T. Hypoglycemic effects of clove (Syzygium aromaticum flower buds) on genetically diabetic KK-Ay mice and identification of the active ingredients. J. Nat. Med. 2012, 66, 394-399. [CrossRef]

92. Sanae, F.; Kamiyama, O.; Ikeda-Obatake, K.; Higashi, Y.; Asano, N.; Adachi, I.; Kato, A. Effects of eugenol-reduced clove extract on glycogen phosphorylase $b$ and the development of diabetes in $\mathrm{db} / \mathrm{db}$ mice. Food Funct. 2014, 5, 214-219. [CrossRef]

93. Okasha, X.; Magaji, R.; Abubakar, M.S.; Fatihu, M.Y. Effects of ethyl acetate portion of Syzygium aromaticum flower bud extract on Indomethacin-induced gastric ulceration and gastric secretion. Eur. J. Sci. Res. 2008, 20, 905-913.

94. Przygodzka, M.; Zieliński, H.; Ciesarová, Z.; Kukurová, K.; Lamparski, G. Effect of selected spices on chemical and sensory markers in fortified rye-buckwheat cakes. Food Sci. Nutr. 2016, 4, 651-660. [CrossRef]

95. Jung, C.H.; Ahn, J.; Jeon, T.I.; Kim, T.W.; Ha, T.Y. Syzygium aromaticum ethanol extract reduces high-fat diet-induced obesity in mice through downregulation of adipogenic and lipogenic gene expression. Exp. Ther. Med. 2012, 4, 409-414. [CrossRef]

96. Pulikottil, S.J.; Nath, S. Potential of clove of Syzygium aromaticum in development of a therapeutic agent for periodontal disease: A review. S. Afr. Dent. J. 2015, 70, 108-115.

97. Tajuddin, A.S.; Latif, A.; Qasmi, I.A. Aphrodisiac activity of 50\% ethanolic extracts of Myristica fragrans Houtt. (Nutmeg) and Syzygium aromaticum (L) Merr. \& Perry. (Clove) in male mice: A comparative study. BMC Complement. Altern. Med. 2003, 3, 6.

98. Saeed, S.A.; Simjee, R.U.; Shamim, G.; Gilani, A.H. Eugenol: A dual inhibitor of platelet-activating factor and arachidonic acid metabolism. Phytomedicine 1995, 2, 23-28. [CrossRef]

99. Raghavendra, R.H.; Naidu, K.A. Spice active principles as the inhibitors of human platelet aggregation and thromboxane biosynthesis. Prostaglandins Leukot. Essent. Fatty Acids 2009, 81, 73-78. [CrossRef]

100. Lima, F.C.; Peixoto-Neves, D.; Gomes, M.D.; Coelho-de-Souza, A.N.; Lima, C.C.; Araújo Zin, W.; Magalhães, P.J.; Saad, L.; Leal-Cardoso, J.H. Antispasmodic effects of eugenol on rat airway smooth muscle. Fundam. Clin. Pharmacol. 2011, 25, 690-699. [CrossRef]

101. Guénette, S.A.; Ross, A.; Marier, J.F.; Beaudry, F.; Vachon, P. Pharmacokinetics of eugenol and its effects on thermal hypersensitivity in rats. Eur. J. Pharmacol. 2007, 562, 60-67. [CrossRef]

102. Tao, G.; Irie, Y.; Li, D.J.; Keung, W.M. Eugenol and its structural analogs inhibit monoamine oxidase A and exhibit antidepressant-like activity. Bioorg. Med. Chem. 2005, 13, 4777-4788. [CrossRef] [PubMed]

103. Bachiega, T.F.; de Sousa, J.P.; Bastos, J.K.; Sforcin, J.M. Clove and eugenol in noncytotoxic concentrations exert immunomodulatory/anti-inflammatory action on cytokine production by murine macrophages. J. Pharm. Pharmacol. 2012, 64, 610-616. [CrossRef] [PubMed]

104. Rodrigues, T.G.; Fernandes, A., Jr.; Sousa, J.P.; Bastos, J.K.; Sforcin, J.M. In vitro and in vivo effects of clove on pro-inflammatory cytokines production by macrophages. Nat. Prod. Res. 2009, 23, 319-326. [CrossRef] [PubMed]

105. Ueda-Nakamura, T.; Mendonça-Filho, R.R.; Morgado-Díaz, J.A.; Korehisa Maza, P.; Prado Dias Filho, B.; Aparício Garcia Cortez, D.; Alviano, D.S.; Rosa Mdo, S.; Lopes, A.H.; Alviano, C.S.; et al. Antileishmanial activity of Eugenol-rich essential oil from Ocimum gratissimum. Parasitol. Int. 2006, 55, 99-105. [CrossRef]

106. Santoro, G.F.; Cardoso, M.G.; Guimarães, L.G.; Mendonça, L.Z.; Soares, M.J. Trypanosoma cruzi: activity of essential oils from Achillea millefolium L., Syzygium aromaticum L. and Ocimum basilicum L. on epimastigotes and trypomastigotes. Exp. Parasitol. 2007, 116, 283-290. [CrossRef]

107. Machado, M.; Dinis, A.M.; Salgueiro, L.; Custódio, J.B.; Cavaleiro, C.; Sousa, M.C. Anti-Giardia activity of Syzygium aromaticum essential oil and eugenol: Effects on growth, viability, adherence and ultrastructure. Exp. Parasitol. 2011, 127, 732-739. [CrossRef]

108. El-Kady, A.M.; Ahmad, A.A.; Hassan, T.M.; El-Deek, H.E.M.; Fouad, S.S.; Althagfan, S.S. Eugenol, a potential schistosomicidal agent with anti-inflammatory and antifibrotic effects against Schistosoma mansoni, induced liver pathology. Infect. Drug Resist. 2019, 12, 709-719. [CrossRef]

109. Kamatou, G.P.; Vermaak, I.; Viljoen, A.M. Eugenol—from the remote Maluku Islands to the international market place: A review of a remarkable and versatile molecule. Molecules 2012, 17, 6953-6981. [CrossRef]

110. Leem, H.H.; Kim, E.O.; Seo, M.J.; Choi, S.W. Antioxidant and anti-inflammatory activities of eugenol and its derivatives from clove (Eugenia caryophyllata Thunb.). J. Korean Soc. Food Sci. Nutr. 2011, 40, 1361-1370. [CrossRef]

111. Grespan, R.; Paludo, M.; de Paula Lemos, H.; Barbosa, C.P.; Bersani-Amado, C.A.; Dalalio, M.M.; Cuman, R.K. Anti-arthritic effect of eugenol on collagen-induced arthritis experimental model. Biolog. Pharm. Bull. 2012, 35, 1818-1820. [CrossRef] 
112. Kim, S.S.; Oh, O.J.; Min, H.Y.; Park, E.J.; Kim, Y.; Park, H.J.; Nam Han, Y.; Lee, S.K. Eugenol suppresses cyclooxygenase-2 expression in lipopolysaccharide-stimulated mouse macrophage RAW264. 7 cells. Life Sci. 2003, 73, 337-348. [CrossRef]

113. Pisano, M.; Pagnan, G.; Loi, M.; Mura, M.E.; Tilocca, M.G.; Palmieri, G.; Fabbri, D.; Dettori, M.A.; Delogu, G.; Ponzoni, M.; et al. Antiproliferative and pro-apoptotic activity of eugenol-related biphenyls on malignant melanoma cells. Mol. Cancer. 2007, 6, 8. [CrossRef] [PubMed]

114. Raja, M.R.C.; Srinivasan, V.; Selvaraj, S.; Mahapatra, S.K. Versatile and synergistic potential of eugenol: A review. Pharm. Anal. Acta 2015, 6, 367.

115. Nam, H.; Kim, M.M. Eugenol with antioxidant activity inhibits MMP-9 related to metastasis in human fibrosarcoma cells. Food Chem. Toxicol. 2013, 55, 106-112. [CrossRef]

116. Hemaiswarya, S.; Doble, M. Combination of phenylpropanoids with 5-fluorouracil as anti-cancer agents against human cervical cancer (HeLa) cell line. Phytomedicine 2013, 20, 151-158. [CrossRef] [PubMed]

117. Al-Okbi, S.Y.; Mohamed, D.A.; Hamed, T.E.; Edris, A.E. Protective effect of clove oil and eugenol microemulsions on fatty liver and dyslipidemia as components of metabolic syndrome. J. Med. Food 2014, 17, 764-771. [CrossRef] [PubMed]

118. Ali, S.; Prasad, R.; Naime, M.; Zafar, H.; Mahmood, A.; Routray, I.; Yalniz, M.; Bahcecioglu, İ.H.; Sahin, K. Dried peel fraction of Citrus sinensis partially reverses pathological changes in rat model of liver cirrhosis. Mediterr. J. Nutr. Metabol. 2011, 4, 57-67. [CrossRef]

119. Said, M.M. The protective effect of eugenol against gentamicin-induced nephrotoxicity and oxidative damage in rat kidney. Fund. Clin. Pharmac. 2011, 25, 708-716. [CrossRef]

120. Oliveira, F.; Andrade, L.N.; de Sousa, E.B.; de Sousa, D.P. Anti-ulcer activity of essential oil constituents. Molecules 2014, 19, 5717-5747. [CrossRef]

121. Pramod, K.; Ansari, S.H.; Ali, J. Eugenol: A natural compound with versatile pharmacological actions. Nat. Prod. Commun. 2010, 5, 1999-2006. [CrossRef]

122. Smith, R.L.; Cohen, S.M.; Fukushima, S.; Gooderham, N.J.; Hecht, S.S.; Guengerich, F.P.; Rietjens, I.M.C.M.; Bastaki, M.; Harman, C.L.; McGowen, M.M.; et al. The safety evaluation of food flavouring substances: The role of metabolic studies. Toxicol. Res. (Camb) 2018, 7, 618-646. [CrossRef] [PubMed]

123. Vijayasteltar, L.; Nair, G.G.; Maliakel, B.; Kuttan, R.; Krishnakumar, I.M. Safety assessment of a standardized polyphenolic extract of clove buds: Subchronic toxicity and mutagenicity studies. Toxicol. Rep. 2016, 3, 439-449. [CrossRef] [PubMed]

124. Anuj, G.; Sanjay, S. Eugenol: A potential phytochemical with multifaceted therapeutic activities. Pharmacologyonline 2010, 2, 108-120.

125. Mishra, R.K.; Singh, S.K. Safety assessment of Syzygium aromaticum flower bud (clove) extract with respect to testicular function in mice. Food Chem. Toxic. 2008, 46, 3333-3338. [CrossRef] [PubMed]

126. Doleželová, P.; Mácová, S.; Plhalova, L.; Pistekova, V.; Svobodova, Z. The acute toxicity of clove oil to fish Danio rerio and Poecilia reticulata. Acta Vet. Brno 2011, 80, 305-308. [CrossRef]

127. Janes, S.E.J.; Price, C.S.G.; Thomas, D. Essential oil poisoning: N-acetylcysteine for eugenol-induced hepatic failure and analysis of a national database. Eur. J. Ped. 2005, 164, 520-522. [CrossRef]

(C) 2020 by the authors. Licensee MDPI, Basel, Switzerland. This article is an open access article distributed under the terms and conditions of the Creative Commons Attribution (CC BY) license (http://creativecommons.org/licenses/by/4.0/). 